\title{
Cidade, história e segregação socioespacial no romance $O$ moleque Ricardo, de José Lins do Rego
}

[City, history and socio-spatial segregation in the novel "O moleque Ricardo", by José Lins do Rego

\section{Bernardo Buarque de Hollanda ${ }^{\mathrm{x}}$}

\section{Regiane Matos}

RESUMO - $O$ artigo detém-se no exame do quarto romance de autoria do escritor José Lins do Rego, procurando mostrar de que maneira, nele, o narrador se desvencilha da paisagem canavieira do interior do Nordeste, e apresenta como locus central de sua ficção o cenário de uma grande cidade nordestina, mais precisamente, a Recife do início dos anos I920. Procura-se evidenciar a maneira pela qual o escritor deslinda a ambiência turbulenta e excludente de uma cidade grande, com seus tipos urbanos subalternos, com a exploração social do trabalho e com seus conflitos políticos. PALAVRAS-CHAVE História e literatura; cidade e ficção; José Lins do Rego. - ABSTRACT - This article focuses on the examination of the fourth novel by the writer José Lins do Rego, trying to show how the narrator in the novel abandons the sugarcane landscape from the interior of the Northeast, and introduces as central locus of its fiction a big Northeastern city, more precisely, Recife from the early I920s. We seek to highlight how the writer - an exponent of the generation that forms the social novel of the I930s - exposes the turbulent and exclusive ambience of a big city, with its subaltern types, its social division of labor and its political conflicts. - KEYWORDS History and literature; city and fiction.

Recebido em 4 de abril de 2018

Aprovado em 8 de março de 2019

HOLLANDA, Bernardo Buarque de; MATOS, Regiane. Cidade, história e segregação socioespacial no romance O moleque Ricardo, de José Lins do Rego. Revista do Instituto de Estudos Brasileiros, Brasil, n. 72, p. IO6-I24, abr. 2019.

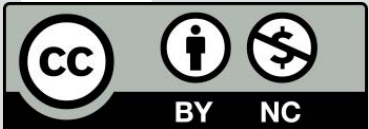

DOI: http://dx.doi.org/Io.II606/issn.23I6-90IX.voi72pIo6-I24

I Fundação Getúlio Vargas (FGV, São Paulo, SP, Brasil).

2 Fundação Getúlio Vargas (FGV, São Paulo, SP, Brasil). 
... a cidade não é apenas [...] uma forma de vida moderna; é a concretização física de uma consciência moderna decisiva.

(Raymond Williams, I990, p. 323).

Vejo-te no escuro, cidade enigmática. (Carlos Drummond de Andrade, "Notícias", 20I2).

José Lins do Rego (I9OI-I957) é conhecido na história literária pela dicção regionalista que caracterizou o romance social nordestino dos anos I930 (CHAGURI, 2009). Embora tenha cultivado, na esteira de Gilberto Freyre, uma relação de animosidade com o movimento modernista dos anos I920, sua obra ficou consagrada no cânone da literatura nacional por contribuir com a renovação da linguagem artística da moderna ficção brasileira (CANDIDO; CASTELLO, I997; BOSI, I975). Como se sabe, seus personagens, suas ações e suas tramas se desenrolam no cenário quase isolado e decadente dos engenhos de cana-de-açúcar, bem como na dramática transição ao universo mecanizado das usinas açucareiras, com o testemunho do processo de modernização agrária no interior do Nordeste.

Em que pese a prevalência humana, social e paisagística do interior nordestino em sua literatura, o presente artigo procura explorar a primeira experiência em que o escritor paraibano se aventurou a incursionar pela ambiência ficcional urbana, O moleque Ricardo (I935), com o "deslocamento do centro de gravidade da ficção da natureza para o homem" (COUTINHO, I99I, p. 430). Tal deslocamento pode ser exemplificado por meio de uma técnica narrativa evocativa e memorialística operada no espaço ficcional de Recife do romance em questão, mas também no Rio de Janeiro descrito e representado em Água-mãe (I94I) e em Eurídice (I947).

Para os limites deste artigo, vamo-nos deter nessa primeira ficção estruturada no ambiente urbano, em particular na cidade de Recife. Além de referência fictícia, o autor, considerado por determinados críticos mais um narrador do que propriamente um romancista, mais um memorialista que um puro inventor, vale-se da oralidade, do peso documental do passado e da sua trajetória biográfica para registrar personagens 
e situações vivenciadas naquela cidade, quando ali residiu, entre I9I9 e I924. A residência do jovem José Lins do Rego na capital pernambucana se deu ao término da Primeira Guerra Mundial (I9I4-I9I8), com o propósito de cursar a Faculdade de Direito do Recife - tradicional espaço de distinção para futuros dirigentes políticos do país -, onde se forma bacharel em meados dos anos I920 (SODRÉ, 20I4, p. 38).

Além da boemia no Bar Grande do Ponto, dos laços de sociabilidade no jornalismo e da formação literária na biblioteca da Faculdade, testemunhou muitas das cenas de greve, de política e de carnaval que retrata no romance. Nesse período, a convivência, a amizade e a influência de Gilberto Freyre - recém-chegado de estudos acadêmicos nos Estados Unidos - são tidas por decisivas na modelagem do ideário estético regionalista do futuro escritor. O intercâmbio com o amigo contribui não apenas para seu contato com os ideais de um modernismo-regionalista em fermentação, como também para o conhecimento íntimo da cidade, com passeios por lugares característicos, típicos de seus bairros, de suas localidades e de sua "cultura popular".

Antes de desenvolver o argumento, alguns dados preliminares são necessários ao presente artigo. Deve-se dizer que o livro é publicado originalmente em julho de I935 - ano político turbulento, com a Intentona Comunista no Brasil e com a tentativa de golpe da frente antifascista Aliança Libertadora Nacional (ANL) - e constitui-se o quarto romance da carreira do escritor. Foi lançado na cidade do Rio de Janeiro, para onde o romancista se transfere naquele mesmo ano.

Lins do Rego deixa Maceió, onde vivia desde I926, sendo levado à capital da República pelo prestígio literário e pela mudança de emprego público, na condição de fiscal do imposto de consumo, função que passa a ser exercida na cidade de Niterói, então capital do estado do Rio de Janeiro. Com dedicatória aos amigos Otávio Tarquínio de Souza (I889-I959) - historiador carioca - e Rodrigo Melo Franco de Andrade (I898-I969) - advogado e intelectual mineiro que foi o primeiro diretor do Serviço do Patrimônio Histórico e Artístico Nacional (Sphan), fundado em I937-, o romance teve tiragem inicial de três mil exemplares.

Isso posto, passamos à apresentação da estrutura do artigo e do seu argumento central. O texto está estruturado em três partes, além da introdução e da conclusão. Na primeira, tecemos um apanhado abrangente e diacrônico da representação das cidades na literatura europeia e brasileira, acompanhando teóricos que se debruçaram sobre o fenômeno urbano e seu correlato ficcional. Não se deixa aqui de pontuar diferenças entre os formuladores de teorias literárias nos países centrais, que assistiram à emergência e consolidação do romance junto ao correspondente desenvolvimento urbano, e aqueles que olharam as especificidades citadinas no ambiente dos países periféricos, dentre os quais se situa o Brasil.

A seção seguinte consiste em uma breve descrição do enredo e da sequência narrativa contida na ficção $O$ moleque Ricardo, de modo a expor uma sinopse ao leitor não familiarizado com o conteúdo do romance.

Em seguida, a terceira e principal parte dedica-se à análise das interpolações entre cidade e engenho, de um lado, e dos contrastes urbanos da Recife representada por José Lins do Rego, de outro. A representação da cidade se esteia em reminiscências históricas do autor sobre o contexto político dos anos I920 e, ao mesmo tempo, se concentra no olhar por assim dizer "lírico" do "moleque" sobre a miséria, a 
precariedade das condições de trabalho subalterno e a segregação socioespacial que marcam a capital recifense, em vias de industrialização, bem como os arrabaldes da região metropolitana.

Por fim, a conclusão retomará pontualmente questões da teoria social para pensar as dimensões históricas, urbanas e culturais ensejadas pela leitura desse romance, cuja importância na literatura nacional relaciona-se a um enfoque a um só tempo ficcional e documental sobre o cotidiano de uma grande cidade no Brasil nos princípios do século XX.

\section{Da CIDAdE MOdERNA Na Europa Às MOdERNIDAdES PERIFÉRICAS NA LITERATURA}

As concepções sobre a cidade moderna acompanharam os processos históricos de transformação econômica, social e cultural na Europa. Desde a transição do feudalismo para o mercantilismo no século XVI, a cidade passou progressivamente a ser o lugar privilegiado de convivência e interação humanas. O advento do Renascimento, a dessacralização paulatina do saber e as inovações do conhecimento científico contribuíram para dar primazia e crescimento célere à vida dos burgos europeus.

No século XVIII ocorrem as duas mudanças de ordem econômica e política que começam a alterar a fisionomia das principais cidades europeias, notadamente Londres e Paris: a Revolução Industrial inglesa e a Revolução Francesa (I789). O desgarramento do camponês da terra e o desmantelamento da relação mestre-artesão na cidade liberam mão de obra para a nova grande unidade de trabalho da era moderna, a fábrica. O declínio da nobreza e a ascensão da burguesia proporcionam a inauguração de uma era de produtividade material que tem o ambiente urbano como palco e a divisão de classes como corolário.

No período setecentista, delineiam-se os primeiros quadros mentais que avaliam positivamente o significado da cidade para a vida social. Segundo o historiador estadunidense Carl Emil Schorske (I9I5-20I5), em sua obra Pensando com a história (2000), a "cidade como virtude" emerge através de três filósofos em especial: Voltaire, Adam Smith e Fichte. O primeiro, expoente do Iluminismo francês, atribuía ao espaço urbano as benesses da liberdade, do comércio e da arte, vendo, no contraste entre ricos e pobres, a base necessária para a prosperidade. $\mathrm{O}$ segundo, teórico do liberalismo econômico britânico, destacava a cidade como lugar promotor de cultura e civilização, cuja mobilidade rompia de vez com a estagnação da fase feudal. O terceiro, discípulo de Kant, percebia os burgos germânicos, ainda infensos à industrialização e guardando traços medievais, como criação pura do povo, capaz de engendrar a moralidade e o espírito comunitário.

O historiador inglês Raymond Williams (I92I-I988), em seu livro O campo e a cidade, endossa a caracterização de Schorske: 
Foi nesse contexto complexo que os observadores setecentistas desenvolveram suas visões da cidade, especialmente Londres, então a principal cidade do mundo. Voltaire via a atividade industrial e a busca dos prazeres refinados como as marcas características da cidade e, portanto, da própria civilização. A idade do ouro, e o Jardim do Éden, por não conhecerem nem a indústria nem o prazer, não eram virtuosos e sim ignorantes: a cidade, Londres em particular, era o símbolo do progresso e das luzes; sua mobilidade social era a escola da civilização e da liberdade. (WILLIAMS, I989, p. 202).

Já o século XIX será menos auspicioso em relação às considerações intelectuais sobre as virtudes urbanas. Tal fato se deve à intensificação da atividade industrial, à migração massiva do campo e à mecanização fabril. O crescimento demográfico se acentua, os conflitos sociais se acirram e a "turba" se adensa nas ruas e nos espaços insalubres (BRESCIANI, I982). Da "cidade como virtude" passa-se, ainda de acordo com os termos de Schorske, à "cidade como vício".

A projeção positiva da cena urbana acede à projeção negativa da sujeira e da miséria citadina. Ainda de acordo com o historiador, a constatação de tais mazelas levou pensadores, como Fourier e outros socialistas utópicos, a esposar ideais arcaístas de regresso a comunidades agrárias e a sociedades pré-industriais isoladas. A própria arquitetura da Londres vitoriana, da Paris napoleônica (Napoleão III) e da Berlim guilhermina expressava a dificuldade dos europeus de se desembaraçar do passado e da tradição.

A tentativa de conter a proliferação caótica de cidades no período oitocentista demandou dos governantes europeus a iniciativa de pensar o espaço a partir do planejamento urbanístico. A modernização pioneira de Paris foi levada a cabo em I859 pelo barão de Hausmann. A função precípua do processo modernizador era ordenar e higienizar a cidade, mediante a introdução de avenidas largas e retilíneas, com traçados geométricos que permitissem os fluxos e refluxos da massa metropolitana no ir e vir de casa ao trabalho. Conforme assinala o historiador brasileiro Ronald Raminelli, em seu ensaio História urbana, o desenvolvimento de planificações urbanas desencadeou a elaboração de várias perspectivas de âmbito filosófico, sociológico e até artístico a respeito da cidade, que se prolongaram até o século XX.

Segundo Raminelli:

Os novos interesses do capitalismo promoveram o surgimento de uma nova concepção de espaço. A mentalidade barroca organizou-o de modo que se tornasse contínuo, ordenado e infinito. Nesta alteração de conceito, os pintores renascentistas como Alberti, Brunelleschi e Ucello deram grandes contribuições quando desenvolveram a noção de perspectiva, criando a ideia de dimensão e, sobretudo, do ordenamento matemático do espaço. Assim sendo, a disposição regular dos prédios com fachadas simétricas, cujas linhas horizontais tendiam ao infinito, promove o prazer estético, prazer semelhante a andar a cavalo pelos campos ou através da floresta. (RAMINELLI, I997, p. I93). 
As soluções estruturais das grandes cidades europeias disseminaram-se para a América do Norte e para a América Latina. Nos Estados Unidos, coube a Robert Moses a tarefa de reformular o espaço de Nova York (BERMAN, 2007) e de projetar o metrô para a cidade de São Paulo entre as décadas de I900 e I920. Na Argentina, como se depreende do romance El amor brujo, de Roberto Arlt, publicado em I932 e ambientado no primeiro quartel do século XX (SARLO, 20IO), registram-se as mudanças de Buenos Aires, mormente em relação ao desenvolvimento dos meios de transporte que ligam a capital argentina às cidades circunvizinhas.

No Brasil, a criação de Belo Horizonte, cidade planejada em I896, mais tarde capital do estado de Minas Gerais, e a Reforma Pereira Passos, de I905, marcam essa época de controle do meio urbano. Concebido e executado pela prefeitura do Rio de Janeiro, o "bota-abaixo" destrói os cortiços do Centro e dá início, em contrapartida, ao crescimento desordenado e à ocupação dos morros e subúrbios cariocas no limiar do século XX. A impopularidade das medidas adotadas está descrita em extensa literatura historiográfica, podendo-se mencionar os historiadores André Nunes de Azevedo (20I6) e José Murilo de Carvalho, este último voltado ao episódio da Revolta da Vacina, um dos temas do livro Os bestializados (I987).

No caso da cidade de Recife, matéria deste artigo e cenário onde se desenrolam as peripécias d'O moleque Ricardo, a capital pernambucana apresenta questões complexas, na medida em que as suas fortes características tradicionais estão jungidas a um enorme impacto urbano-industrial, sem que qualquer reforma modernizadora do governo se opere.

A propósito dessa cidade, convém abordar o ensaio do filósofo Emmanuel Carneiro Leão (I99I). Nele, o autor evidencia como a decomposição das estruturas agrárias arcaicas, baseadas em uma cultura oral ágrafa, de riqueza e criatividade incessantes, rompeu um ciclo de equilíbrio do homem com a terra e forjou a figura do migrante, desenraizado e desintegrado do contexto técnico-científico-educacional. A miséria mais radical das cidades subdesenvolvidas, coexistindo com processos de modernização, é assim descrita por Carneiro Leão:

Pela primeira vez na história do mundo aparece a figura da miséria radical no proletariado da revolução industrial. Esta nova figura resulta de dois mecanismos historicamente desconhecidos: a decomposição e a expropriação estruturais, ambos constitutivos da industrialização. As populações das sociedades agrárias pré-industriais conheceram graus quantitativamente muito mais intensos e extensos de pobreza. Mas a sua miséria não era radical. Pois as estruturas sociais e culturais de sua ordem asseguravam uma existência integrada de indivíduo, comunidade e instituição. A riqueza de convivência pessoal e social oferecia continentes e níveis, que as sociedades desenvolvidas da ordem industrial não conhecem nem suspeitam. O que marca de novidade histórica a ordem industrial é que toda a sociedade vem sendo trabalhada pela miséria radical, de alto a baixo, em todos os estamentos de suas estratificações sociais. O proletariado provém de um processo violento de desraigamento e desterro. (LEÃO, I99I, p. 232 - grifos nossos). 
Ao longo do século XX, a transição do campo à cidade se propagou de maneira desmesurada. Nos dias de hoje, estima-se que $80 \%$ da população mundial habita em aglomerados urbanos. No caso brasileiro, a realidade contemporânea contradiz uma série de projetos planificadores de ordenamento, funcionalização e higienização, como atestam as cidades-satélites de Brasília, ícone da modernidade nacional nos anos I950 e I960. As megalópoles galvanizam cada vez mais o espaço e trazem desafios em maior escala à humanidade, a exemplo da poluição, da violência, da superpopulação, da disparidade econômica e da intolerância étnica.

Retomando um aspecto salientado no princípio deste artigo, é possível dizer que o interesse da literatura ocidental moderna pela temática das cidades amplia-se com a fixação do capitalismo na Europa e a instauração dos valores burgueses sobre o indivíduo e a sociedade. Uma ótica literária se coaduna ao meio urbano, variando de perspectiva segundo a subjetividade do poeta ou do prosador.

Renato Cordeiro Gomes, em seu artigo "A cidade, a literatura e os estudos culturais" (I999), escalona três níveis de percepção literária da paisagem citadina: I) descrição toponímica da cidade pelo escritor e reconhecimento de seus aspectos físico-geográficos; 2) ênfase nos dados socioculturais e nos hábitos dos personagens, facultando um entendimento de inserção humana em seu habitat; 3) dimensão simbólica da cidade, em que os elementos urbanos são vistos como uma rede cartográfica, em que se imiscuem imaginário autoral, memória da cidade e "cidade da memória”.

Coube ao romantismo europeu da primeira metade do século XIX uma das primeiras apreciações na história da literatura a propósito das cidades modernas. Ã cidade, os românticos atribuíam as noções de desordem, agitação e falsidade, enquanto ao campo associavam lugares idílicos de tranquilidade e reencontro do ser humano com a natureza. A breve passagem do escritor inglês D. H. Lawrence, citado por Raymond Williams, ilustra este ideário estético: "A verdadeira tragédia da Inglaterra, a meu ver, é a tragédia da feiura. O campo é tão lindo: a Inglaterra feita pelo homem é tão horrenda" (Williams, I989, p. 359).

Já o romance realista da segunda metade do século XIX não se esquiva da cidade moderna, aquiescendo-a como realidade cada vez mais imponente e inelutável. Em Balzac, a imagem da cidade remete a um ambiente de mobilidade social e complexidade constante.

Quanto a Dickens, diz Williams (I989, p. 2I6):

[...] a essência da visão dickensiana de Londres não pode ser ilustrada por dados topográficos nem exemplos locais. Ela reside na forma de seus romances: no tipo de narrativa, no método de caracterização, na facilidade de tipificação. Tanto faz dizer uma coisa ou seu oposto: a experiência da cidade é o método da ficção; o método da ficção é a experiência da cidade. O mais importante é que a visão - e não se trata de uma visão única, e sim de uma dramatização contínua - é a forma da escritura.

Ainda na segunda metade dos Oitocentos, avulta a poesia de Baudelaire, que situa a cidade para além do bem e do mal, acima de juízos de valor. A modernidade parisiense é como uma nova paisagem que se sobrepõe à paisagem natural, onde o 
flâneur solitário perambula, anônimo, em meio à agitação febril da multidão. Nos interstícios do capitalismo, o olhar lírico do poeta capta o âmago da urbe moderna, no que ela compreende de humano e desumano, de extasiante e ignominioso, no que ela encerra de ambiguidade e polissemia.

O século XX irá consagrar uma série de movimentos artísticos de ruptura, chamados genericamente de modernismo, que farão odes ao triunfo da máquina, da velocidade e do inconsciente no mundo contemporâneo. Na literatura francesa, destacam-se André Breton (I896-I966) e Louis Aragon (I897-I982). O primeiro, através de sua obra Nadja (I928), mostra Paris metamorfoseada em serpente, simbolizando uma cidade movediça e surreal. O segundo, no livro Le paysan de Paris (I926), relata a cidade sob uma atmosfera densa, timbrando o cotidiano de artificial, de surreal, de fantástico.

No Brasil, um dos expoentes das letras modernistas foi o polígrafo Mário de Andrade. Em sua rapsódia Macunaíma (I928), a técnica narrativa do escritor paulista procura sintetizar alegoricamente um país cindido entre selva e cidade, interior e litoral, evidenciando como esses polos antagônicos da nação têm equivalências de incompreensão para o habitante de um lugar e outro. Quando o herói picaresco adentra a metrópole paulistana, o espaço urbano mecanizado afigura-se uma selva ao revés, povoada por uma profusão heteróclita de máquinas e luzes incognoscíveis para um selvagem afro-ameríndio.

Ainda no que toca à literatura brasileira do século XX, o supracitado autor Renato Cordeiro Gomes ressalta traços literários interessantes, que podem ser utilizados para pensar os pressupostos norteadores dos pares do romancista e cronista José Lins do Rego, a serem analisados mais à frente:

Esses aspectos podem ser observados na literatura modernista brasileira, a exemplo dos poemas de Mário de Andrade, de Carlos Drummond de Andrade, ou de Vinícius de Moraes, ou Manuel Bandeira, ou ainda em narrativas de Lima Barreto, ou João do Rio, que cenarizam em suas grafias urbanas as transformações do Rio de Janeiro do início do século, testemunhando e documentando o processo de modernização excludente instaurado no Brasil pelos donos da República. Essas narrativas, entretanto, a exemplo dos textos de Marques Rebelo (anos I930), voltam-se de preferência para os aspectos mais característicos, mais provincianos, presos a essências localistas, tendo por base a territorialização e o documental, dentro da tradição nacional. (GOMES, I999, p. 27 - grifos nossos).

Nos anos 1970, I980 e I990, com a voga do desconstrucionismo, a cidade é vista a partir dos efeitos da globalização e da condição pós-moderna (LIPOVETSKY, 20II). A presença de um centro articulador se exaure, e ganharam força os múltiplos sentidos polifônicos da cidade. A cidade global tem uma gama de representações, em que o vertiginoso deslocamento de indivíduos no domínio urbano condiciona a posição de "entrelugar" e esboroa a identidade do Estado-nação, para falar com o indo-britânico Homi K. Bhabha (I998).

Na literatura ocidental, desponta o nome de Ítalo Calvino, que vê a cidade sob a égide de uma tensão entre a racionalidade geométrica e o emaranhado de existências 
humanas. No Brasil, Rubem Fonseca, por seu turno, expressa o fim da utopia na literatura brasileira contemporânea, onde seus personagens vagam pela cidade cruel e violenta, caindo da redoma da introspecção e do desencantamento.

\section{QUADRO SINÓTICO DO ROMANCE O MOLEQUE RICARDO}

Feito um apanhado geral dos modos pelos quais a cidade foi apreendida pela literatura europeia e brasileira ao longo do tempo, passemos à obra específica do escritor José Lins do Rego. $\mathrm{O}$ exame do romance $O$ moleque Ricardo à luz da representação da cidade requer, de início, a sumarização das linhas mestras que enredam essa obra.

Nela se narra a história de Ricardo, um jovem pobre e negro, de I6 anos de idade. O protagonista sai do engenho Santa Rosa, espaço fictício do interior da Paraíba, com suas terras de massapê, onde também se passam as ficções regionais do denominado ciclo da Cana-de-açúcar de Lins do Rego - Menino de engenho (I932), Doidinho (I933) e Banguê (I934). O personagem abandona o ambiente familiar, rural e canavieiro para ir morar em Recife, capital de Pernambuco e importante centro histórico do nordeste brasileiro. A trama romanesca, subdividida em 33 capítulos, com extensões variadas entre si, é ambientada nas décadas de I9Io, I920 e I930, contemporâneas ao escritor e a fatos históricos internacionais, como a Revolução Russa de I9I7, embora as datas sejam omitidas pelo narrador.

Em um típico processo de proletarização urbana, sob a tentação de migrar para uma cidade grande, o "moleque de bagaceira" sobrevive na cidade graças a pequenos expedientes ou a subempregos não qualificados. De início, serve como criado de dona Margarida na Rua do Arame, esposa do condutor do trem da Great Western que o trouxera do interior num vagão de segunda classe.

De criado de casa de família, vai trabalhar como entregador de pães no bairro da Encruzilhada, ao norte da cidade. Na condição de balaieiro, serve à padaria, oferecendo e entregando pães com a corneta de sua bicicleta pelas ruas de Recife. Em seguida, já condicionado pelo esgotamento físico do regime laboral, ao lado de outros companheiros, trabalha como requentador de uma panificadora da Rua do Cisco, nas proximidades do mangue, em direção a Olinda.

Embora sob incipiente desenvolvimento industrial, a cidade de Recife, com seu dinamismo e grandiosidade, amedronta o rapaz, que se sente um estrangeiro. Este se impressiona com a exploração do patrão sobre os empregados, com a atmosfera cosmopolita da elite senhorial, com a multidão que pulula pelos espaços públicos e com os bairros que abrigam a população pobre, em meio à precariedade de mocambos e alagadiços. Ao longo da história, que se inicia com a fuga do engenho e a viagem de trem rumo à capital, Ricardo mais de uma vez é acometido de saudades da sua família, especialmente de sua mãe Avelina, a quem endereça cartas, de sua irmã Salomé e de sua tia Galdina.

Na cidade, uma vez evadido do canavial, o "moleque" assiste à agonia e à morte do amigo e masseiro Florêncio, que atua no sindicato a fim de conquistar melhores salários. Dr. Pestana, líder dos operários, reúne trabalhadores e estudantes para lutar contra o governo e supostamente instituir uma "república socialista em Pernambuco" 
(REGO, 20II, p. I45). O Exército e a polícia investem contra os “meetings" (REGO, 20II, p. I49) dos estudantes e os atos dos grevistas, seus piquetes e seus manifestos em Recife. Junto ao que ocorria também na capital, a repressão estendia-se a outros municípios do estado: Olinda, Palmares, Paulista e Jaboatão dos Guararapes.

$\mathrm{O}$ amigo Florêncio, desamparado pelo sindicato, acaba morto, em razão de complicações de saúde que o acompanharam depois do atentado à Faculdade, onde se sublevavam os estudantes. Mesmo o trabalho de um sacerdote de xangô mostra-se incapaz de recobrar a vida do amigo agonizante. Enquanto isso, os membros do movimento percebem que estavam sendo ludibriados por Pestana, típico demagogo rodeado de capangas, e por Clodoaldo, corrupto.

Ricardo observa os conflitos com certa ingenuidade, não entende as artimanhas da política e sofre com a perseguição ao colega de trabalho. Mas, a despeito das peripécias da política, segue sua vida cotidiana de entregador de pães. Mais à frente, apaixona-se por uma moça e tem com ela suas primeiras experiências sexuais. A vivência da cidade faz com que se encante pelo carnaval de rua e passe a acompanhar os ensaios de um bloco carnavalesco. Desfila no Paz e Amor, com sede na rua do Cisco. Engaja-se na competição entre os blocos - Toureiros, Vassourinhas, Pás-Douradas -, admira os Lenhadores de Olinda, "clube de fama" (REGO, 20II, p. I78), e assiste ao maracatu do grupo Leão Coroado, em Recife.

Certa feita, o moleque passa a namorar uma rapariga chamada Odete. A moça habita uma área muito pobre da cidade, onde ganha a vida mediante expedientes de caça a caranguejos no mangue, entre córregos e alagados, um dos símbolos da miséria extrema retratada no romance. Os dois, depois de um tempo, casam-se, mas o pai de Odete, capanga do cais do porto, sofre um atentado e tem uma perna amputada. Odete adoece gravemente, e Ricardo, imaturo, arrepende-se do casamento.

Ricardo sente-se sem rumo na vida, deseja voltar ao engenho e evadir-se do Recife. Trabalha ainda como operário na construção das novas linhas de bonde, desencantando-se ainda mais com a experiência na grande cidade e aspirando pelo retorno ao campo. Nesse ínterim, aparece o masseiro Sebastião, que assume o comando operário, e o movimento insurrecional dos trabalhadores recrudesce. $\mathrm{O}$ moleque vê todos os seus colegas de trabalho integrados nas reivindicações, mas ele mesmo não se identifica plenamente com as ações grevistas.

A ausência de perspectivas leva-o a aderir novamente à greve, que é mais uma vez debelada pelas forças policiais. Como punição, Ricardo, Sebastião e os demais companheiros, muitos deles ingênuos e inocentes, embarcam para o degredo no presídio da ilha de Fernando de Noronha, para onde é enviada toda sorte de ladrões, degredados e criminosos. É lá, por exemplo, que conhece o sertanejo Manuel, com três mortes no cangaço e contador de romances de cordel.

Sob o cenário desolador da condenação, termina o "triste fim" do moleque Ricardo, um final por assim dizer "infeliz", considerado por Otto Maria Carpeaux um dos maiores encerramentos do romance brasileiro. Superlativos à parte, poder-se-ia ao menos comparar a pungência da cena derradeira àquela de Policarpo Quaresma, de Lima Barreto, em meio à perplexidade de uma interrogação kafkiana: “-Que fizeram eles que vão pra Fernando? Ninguém sabe não!” (REGO, 20II, p. 3I5). 


\section{O ENGENHO E A CIDADE: POLOS RELACIONAIS}

A partir dessa breve súmula do enredo da obra, cuja narrativa salienta o "esforço libertário do êxodo" na busca do personagem pela sua "libertação moral” (MELO, I99I, p. 279), o primeiro argumento a ser levantado nesta terceira e última seção diz respeito à concepção de cidade sugerida na ficção. Cumpre ressaltar que esta se encontra sempre referida à noção antípoda de campo, espécie de imagem em negativo ou pano de fundo implícito da história. O mundo do canavial é a todo o tempo o parâmetro contrastivo de Ricardo em suas tentativas de compreender a cidade de Recife e o comportamento dos seus habitantes. O engenho Santa Rosa e a capital pernambucana podem ser vistos, portanto, como duas unidades socioespaciais relacionais que se remetem mutuamente.

Sob a ótica reminiscente do moleque Ricardo, o campo e o interior são lugares nos quais prevalecem as relações interpessoais, afetivas e familiares. O convívio com os demais moradores da região é diluído, e as relações humanas mostram-se mais dispersas em virtude da distância geográfica entre o trabalho e os espaços de moradia no engenho. Neste, o coronel é a figura central, arquetípica do poder no universo canavieiro, ladeado por capangas e toda a sorte de jagunços e seguranças privados. Acima até mesmo do beato, figura de autoridade religiosa, o patriarca possui um capital simbólico e econômico de realce naquela hierarquia interna, infensa à presença do Estado.

Para retomar aspectos mencionados no tópico anterior, levantados por Raymond Williams (I989), o romance de Lins do Rego sugere que a natureza no campo é aberta, pujante e envolvente. O ser humano vale-se do meio natural e dos animais, seja como meio de transporte, seja para extrair os alimentos de que necessita. Ao mesmo tempo, a vida sugerida no engenho é marcada pela estagnação, pela ausência quer de aspirações sociais, quer de perspectivas econômicas. Com efeito, tal estado de coisas impele seu habitante à emigração e à busca por uma alteridade promissora, via de regra projetada na vida da cidade.

A maioria dos trabalhadores do canavial é pobre e servil, porém sua pobreza e sua servidão situam-se num patamar em que a fome não compromete a sobrevivência humana. Em consonância com o salientado por Leão (I99I) em passagem aludida anteriormente, sua situação permite uma precária, porém mínima, subsistência. A miséria da cidade e o contraste com o campo são assim descritos por José Lins do Rego (2OII, p. II8):

Os meninos eram amarelos como os do engenho, mas eram mais infelizes ainda. Lá, eles tinham o rio e a capoeira para entreter os vermes e o impaludismo. Os filhos de Florêncio faziam concorrência com os urubus, cascavilhando no lixo [...]. Ter fome era o diabo. No engenho o povo se aliviava na fava, na batata-doce. Ali não. Era mesmo não ter o que comer.

Todavia, o insulamento do engenho não é total. Este está ligado à cidade através do trem, objeto que simboliza a mobilidade do capitalismo industrial do século XIX. Assim, ao optar por fugir do universo canavieiro, a chegada ao Recife é descrita pelo 
moleque como a conquista da liberdade, como o descortinar de um novo mundo. A capital extrapola o horizonte de quem se acostumou à monotonia do engenho.

A ótica do migrante guia-se pelo alumbramento, isto é, pelo despertar de todos os sentidos. A cidade se apresenta na ficção como uma espécie de torvelinho urbano, tão absorvente quanto estranha e desnorteadora para um provinciano recém-chegado. As relações sociais são em princípio impessoais e anônimas, sendo regidas sob a égide da divisão fundamental capital/trabalho. $O$ proletariado concentra-se no centro urbano, ao passo que as zonas circundantes favorecem outras formas de vida e de sobrevivência, com a comida, as habitações e as doenças típicas do mangue. $\mathrm{Na}$ narrativa de Lins do Rego trata-se de uma deterioração do homem, não da natureza. Pouco a pouco, Ricardo vê e sente a miséria, seu contraste com o luxo da burguesia, e desenvolve um sentimento de solidariedade para com os desvalidos.

As relações humanas são mais diretas e intensas, massificadas e tensionadas em seu cotidiano de idas e vindas da casa ao local de trabalho. Em termos arquitetônicos, ao contrário do espaçamento das moradias no engenho, as casas citadinas se alinham de forma horizontal e contígua. Marcado por uma narrativa afetiva e por uma memória de cunho documental, José Lins do Rego dá registro e valoriza o ato de chegada de Ricardo aos arredores da capital pernambucana. O estranhamento inicial e as primeiras sensações do moleque com o fervilhar da cidade grande são assim narrados:

O trem puxava, as estações se sucediam. Ricardo notava que a gente que entrava pelo vagão já era diferente, gente mais despachada, ganhadores pedindo frete, moleques vendendo jornais. O Recife estava próximo. A cidade se aproximava dele. Teve até medo. Falavam no engenho do Recife como de uma Babel. "-Tem mais de duas léguas de ruas". "Você numa semana não corre”. E bondes elétricos, sobrados de não sei quantos andares. E a gente na rua que só formiga. O dia todo é como se fosse de festa. Tudo isso agora estava perto dele. Via gente de sua cor e de sua idade entrando e saindo do carro como se fosse em casa. E ele ali encolhido no canto. Que diabo era aquilo? Medo, uma covardia de menino fora da saia da mãe. A cidade começava a mostrar os primeiros sinais. Arraial. Viu um bonde amarelo. Era o primeiro que se apresentava aos seus olhos. Não era tão grande como diziam. ENCRUZILHADA. Casa de gente pobre pela beira da linha, jaqueiras enormes, mulheres pelas portas das casas. E agora o Recife. Tudo aquilo já era o Recife que estendia as suas pernas, que crescia, que era o mundo. (REGO, I984, p. 79-80).

Ao contrário da centralidade do chefe de família patriarcal, cujo poder de mando é personalizado em sua figura, na cidade o governo estadual é, em princípio, impessoal e constituiu-se em símbolo político central. Dotado de autonomia federativa, este se organiza através de um aparelho burocrático e repressivo. Integrante da federação, o estado de Pernambuco tem de se submeter, por sua vez, à presidência da nação, o que não ocorre no romance, deflagrando intervenções, rebeliões e a presença do Exército na trama.

O litoral, a capital e a cidade são lugares vistos como cosmopolitas, abertos, pois, às influências externas e à circulação de notícias internacionais. Recife torna-se palco de agitações econômicas e sociais. Em detrimento disso, a natureza não 
demonstra sua exuberância no campo. Na cidade, o homem não tem ligação telúrica com seu meio, e a miséria destrói o meio natural. Tratada mais como "vício" do que como "virtude", para evocar os termos de Carl Schorske (2000), a dignidade humana é afetada pela fome e pela dependência do dinheiro.

Uma vez instalado na cidade de Recife, outra polaridade é colocada para o migrante. O eixo principal deixa de ser o binômio engenho/cidade - ou interior/litoral -, para se tornar Norte/Sul. Essa polaridade era assim empregada na primeira metade do século XX, quando ainda não haviam sido estabelecidas as categorias regionais Nordeste/Sudeste na regionalização do Brasil. No romance, Recife passa a aparecer contraposta ora ao Rio de Janeiro - centro político do país - ora a São Paulo - centro econômico nacional. Rio de Janeiro e São Paulo figuram como capitais promissoras do ponto de vista econômico, além de apresentarem centralidade política, enquanto Recife oferece poucas perspectivas de prosperidade.

Em continuidade ao que é sugerido em I935 pelo romance $O$ moleque Ricardo, pode-se extrair também o próprio sentido percorrido pela migração no Brasil, retratada em marcos do cânone literário, como Vidas secas (I938), de Graciliano Ramos, ou em poemas andejos de retirantes, como Morte e vida severina (I945), de João Cabral de Melo Neto.

Se as partes iniciais do romance se dedicam a endossar o contraste dualístico engenho-cidade, reaparecendo de tempos em tempos de forma evocativa na narrativa, o ambiente urbano é pouco a pouco incorporado, naturalizado e generalizado. A cidade de Recife é apresentada no romance de José Lins do Rego como um labirinto ruidoso, no qual a multidão circula celeremente a pé, de bicicleta, nos automóveis e nas maxambombas eletrificadas.

A elite trafega nos carros particulares, símbolos de distinção, ao passo que a malha urbana é entrecortada pelos bondes da companhia estrangeira Tramway, pelas pontes do período colonial e pela geografia dos dois rios mais importantes da cidade: o Capibaribe e o Beberibe. Enquanto a locomotiva liga a capital às cidades do interior, o cais do porto é o elo de contato da cidade com o "sul" do país e com o restante do mundo. Na zona portuária atracam as embarcações estrangeiras, e dela partem as embarcações nativas.

Ricos, pobres, agregados e párias distribuem-se pelos bairros. Suas casas são transfiguradas pelo moderno, convertendo-se nos sobrados, como os da Rua Nova e da Rua do Imperador, - de arquitetura refinada - e nos mocambos - de arquitetura rústica. As moradias representam uma importante dimensão explorada em termos histórico-sociológicos por Gilberto Freyre (2004), em sua série sobre a história da família patriarcal no Nordeste do país, iniciada com Casa-grande er senzala (I933 com segunda edição de I937). A visão de Freyre sobre a célula básica de formação da sociedade brasileira tem continuidade em Sobrados er mucambos (I936), livro contemporâneo, pois, de $O$ moleque Ricardo.

$\mathrm{Na}$ ficção, a parcela mais pobre vive próxima ao mangue, alimenta-se de caranguejo e tem de suportar o odor fétido de diversas localidades que sofrem os efeitos da urbanização desacompanhada de mínimo saneamento. A cidade grande, embora sugira o desenraizamento e o anonimato, não elimina por completo o caráter de suas raízes rurais. Ela não impede a existência de relações 
comunitárias, interpessoais e vicinais, com o estabelecimento de redes de solidariedade nas quais todos se conhecem e podem levar uma vida até certo ponto provinciana. José Lins do Rego descreve, através do narrador em terceira pessoa, a lida cotidiana do moleque Ricardo:

O serviço era pesado, mas o ordenado de um príncipe em comparação com os Io mil réis do condutor. A princípio sentiu saudades das plantas de Dona Margarida. Não pesavam nas costas como o balaio de pão. Começava às cinco horas da manhã. Lavava o rosto, comia o seu pedaço de pão com café, e o balaio cheio o esperava. Bem que pesava no começo e sentia na cabeça o calor do pão quente. A manhã era alegre, e o trabalho para Ricardo não era castigo. Saía pela Encruzilhada. As casas fechadas. Só se viam pelas ruas operários que esperavam o trem e os que levavam, como ele, balaios de pão na cabeça. O homem que ia atrás dele tocava uma corneta fanhosa. Enchia os sacos da freguesia dependurados pelos portões de ferro. A corneta acordava as criadas. Agora já ia por João de Barros, e o sol esquentava-lhe o rosto molhado de suor. Sentia a terra tremer nos pés quando a maxambomba passava por perto fazendo um barulho medonho. Olhava para o trem apinhado de gente pobre que ia para o pesado. Com pouco o balaio já não pesava na cabeça. Estava findo o serviço da manhã. (REGO, I984, p. 90).

Os elementos figurativos dos topos urbanos são, entre outros: a padaria, a fábrica, o sindicato, a faculdade, a sede do jornal (Diário de Pernambuco), o hospital, o bonde, a praça pública, o clube, o cinema (Cine Espinheiro) e o terreiro de feitiçaria. Dentre os personagens componentes dessa paisagem urbana, estão tipos humanos como o galego (dono da padaria), o masseiro, o balaieiro, o forneiro, o catraieiro, o motorneiro, o ferroviário, o operário, o policial, o jornalista, o bacharel, a dona de casa, o pai de santo e o cangaceiro³.

De acordo com o crítico Virginius da Gama e Melo (I980, p. 94), O moleque Ricardo constitui um "mural político-social do Recife" e uma “antevisão da movimentação de massas”. Com seu "talento instintivo”, Lins do Rego é capaz de tematizar a proletarização urbana, centrada no dia a dia de uma padaria, que leva ao esgotamento físico de Ricardo e de seus colegas de trabalho, mas também das facetas sociais da lida dos trabalhadores do Recife como um todo. A ambiência da urbe era assim apresentada em seu "corte vertical”, isto é, mediante a técnica de narração literária proposta pelo estadunidense John dos Passos (I896-I970) e pelo inglês Aldous Huxley (I894-I963), em período contemporâneo à geração brasileira de José Lins do Rego. Por intermédio dele, o escritor dedica-se à descrição orgânica, com resquícios de naturalismo, do todo social, em "equilíbrio dinâmico", e à visão em profundidade das personagens:

3 O cangaceiro é uma figura bandoleira e criminosa, instrumento de poder da oligarquia rural, que vem da caatinga para pilhar, incendiar e assombrar a cidade, a exemplo do que fazem no bairro de Santo Amaro no enredo do romance. 
Todas as camadas sociais são apresentadas pelo romancista paraibano, não em sistema de justaposição, mas de entrosamento dentro da fórmula tradicional do romance, o que lhe dá um interesse romanesco que não encontramos nos outros romancistas que se pretenderam o corte vertical da sociedade. (MELO, I99I, p. 285).

Recife, além de cidade portuária, também apresenta crescente processo de crescimento demográfico e de industrialização, com a edificação de uma série de fábricas e com a chegada dos proprietários de terra e dos usineiros, transplantados para a capital. Em razão disso, acentua-se a divisão social do trabalho, o conflito das classes sociais em formação e a exploração do industrial sobre o operário, despertando-lhe uma consciência coletiva.

No final dos anos I9I0, os ecos da Rússia revolucionária, liderada por Lênin, em luta contra o czarismo e recém-convertida ao comunismo, chegam também ao litoral nordestino e estimulam os trabalhadores à organização sindical. Na trama ficcional, a força do operariado é catalisada por um líder socialista, mas este, em seguida, revela-se um farsante, um arrebatador de massas, mais interessado no poder pessoal e na eleição para deputado federal que na libertação de sua classe.

A título de contextualização, convém lembrar que, no Brasil, a Confederação Operária Brasileira datava de I908 e, já em I9I7, ano revolucionário que assistiu a grandes greves gerais pelo país, a entidade congregava milhares de membros nas cidades mais industrializadas do país. Segundo Benjamin Abdala Jr., professor da USP, em edição comentada de $O$ moleque Ricardo, publicada em 20II, os líderes operários de então se dividiam entre anarquistas e "maximalistas", isto é, bolcheviques. Em I922, na esteira desses acontecimentos, é fundado o Partido Comunista do Brasil, que viria a ser conhecido pela sigla PCB.

A descrição ficcional torna-se nessas passagens parte de um relato de reconstituição histórica mais amplo ao registrar a ascensão do operariado e ao documentar a crise política do início da década de I920. Sabe-se que José Lins, em I922, tomou parte na campanha eleitoral do estado e apoiou o candidato ao governo Manoel Borba. Em tal contexto de aparecimento de lideranças políticas e operárias, as organizações proletárias chegam a conseguir mobilizar boa parte do estado de Pernambuco, fato que incomoda e chama a atenção do presidente do país, Epitácio Pessoa. Este intervém em seguida, com a convocação do Exército para combater os trabalhadores rebelados.

Os estudantes universitários, de sua parte, e alguns jornais de Recife, como o Diário do Povo, unem-se aos sindicatos na luta revolucionária. A calamidade social e a situação inóspita de vida em que se encontra Recife, a despeito de todo o impulso de desenvolvimento alavancado pela indústria, são caracterizadas no romance desta forma:

Morava muita gente naquela beira de mangue. De lá saíam homens que iam pegar açúcar no cais, cinco arrobas na cabeça, das barcaças para o armazém; operários de fundição; balaieiros; aleijados que viviam de esmolas pelas portas. E, no entanto, aquele curtume ali perto fedendo, empestando as águas que tanto serviam, matando os peixinhos. Só os caranguejos resistiam. Eles e os urubus. Ricardo achou então que havia gente mais pobre do que os pobres do Santa Rosa. Mãe Avelina vivia de barriga 
cheia na casa-grande. Se ela viesse para ali e caísse naquela vida? Se os seus irmãos saíssem para o lixo, cascavilhando com os urubus? Florêncio ganhava quatro mil-réis por noite. O que eram quatro mil-réis no Recife? Uma miséria. Por isso o outro falava em greve, com aquela força, aquela vontade de vencer. (REGO, I984, p. II5).

Em relação aos conflitos raciais, as diferenças são marcantes e espelham os contrastes econômicos. Rico é tomado como sinônimo de branco, na mesma proporção em que pobre equivale a negro. A escravidão é uma herança residual do passado, ainda não dissipada no contexto de princípios do século XX. Aqui e ali aparecem na narrativa personagens alforriados, como seu Abílio, pai de Odete. Muitos negros também descendem do tempo do regime patriarcal, como o próprio moleque Ricardo. O negro, dessa maneira, ocupa o lugar mais inferior na hierarquia econômica, onde sua imagem é associada à do pobre e à do empregado subalterno.

Por outro lado, a imagem do negro está associada às religiões africanas, que em Recife são designadas pelos nomes de catimbó e feitiçaria. A elite considera as práticas religiosas um embuste e vê o pai de santo com desconfiança. Apesar disso, os ricos admitem a exuberância religiosa do negro e sua ampla inserção na cultura popular e no carnaval da cidade.

\section{CONSIDERAÇõES FINAIS}

O caminho de leitura do romance zeliniano desenhado no presente artigo alinha-nos em consonância com o ensaio do crítico literário Manuel Cavalcanti Proença intitulado “O negro tinha caráter como o diabo!” (I966), texto que se tornou indissociável da apresentação do romance a partir de sua sétima edição. Conquanto ambientado em Recife, trata-se para o crítico ainda de um "esgalho" (PROENÇA, 2OII, p. I3) do memorialismo e de um "satélite" do ciclo da Cana-de-açúcar. Nele, o crítico conclui que:

José Lins do Rego não foi escritor engajado. Entretanto, na simples escolha do personagem central deste livro, unicamente no desenhar os perfis de Ricardo e do dr. Carlos, ele estava dando o testemunho de que algo apodreceu e uma nova sociedade está em gestação. Tal como Ricardo, ele não compreende a greve, não gosta de violência, não acredita na vitória de uma causa entre cujos líderes há corruptos como Clodoaldo, ambiciosos como Pestana. Mas, ao fechar o livro, ninguém estará contra os operários de Recife, ninguém terá boa recordação de seu Alexandre, ninguém concordará com o exílio do moleque para Fernando de Noronha.

É que o romancista, autêntico, sincero, de olhos abertos à realidade, sentiu o drama da miséria dos mocambeiros, a miséria de Florêncio, morrendo no mangue, enquanto o patrão pagava automóvel para a mulata se pavonear no Carnaval. Viu o drama humano e retratou-o, como tinha retratado o dos párias do engenho. Sem saber, estava oferecendo um documento de grande importância para a estruturação do pensamento 
político das novas gerações nordestinas. Tanto mais válido quanto desvinculado de intenções e de sectarismo ideológico.

Por tudo isso, $O$ moleque Ricardo tem lugar à parte em sua bibliografia. Pretendeu ser a história de um negro bom e manso que a cidade seduz, escraviza, tortura, mas acaba iluminando. No final, o que nos deu foi o retrato de uma sociedade em conflito à procura de novos caminhos. Que hão de vir (PROENÇA, 20II, p. 34).

Assim, à guisa de conclusão, vamos recorrer a duas observações pontuais sobre o romance que podem ser ancoradas na teoria social. A primeira delas relaciona-se ao livro de Norbert Elias intitulado Sobre o tempo (I998). Nela, o sociólogo alemão destaca a correlação entre tempo cronológico e tempo social. A noção de tempo na sociedade moderna, materializada nas grandes cidades, está subsumida à regulação do desenvolvimento técnico. Segundo Elias, o homem moderno incutiu uma concepção temporal condicionada pelo trabalho mecânico, repetitivo e burocrático, ao passo que o homem não ocidental vive mais próximo a um padrão de tempo dependente dos movimentos cíclicos da natureza.

Isso remete à dualidade cidade-engenho, como duas realidades socioespaciais contraponteadas no decorrer do livro, conforme procuramos demonstrar. No engenho, o homem está mais próximo do calendário e dos ciclos naturais, ao passo que na cidade os meios técnicos se assenhoram do tempo social e passam a reger a vida humana de forma mais intensa e enclausurada.

A segunda observação conclusiva é sugerida pela leitura do texto de Mike Featherstone, "Localismo, globalismo e identidade cultural" (I996). Nele, o autor se contrapõe aos arautos do niilismo técnico-científico ao asseverar que o processo de globalização, a expansão da circulação econômica e a instantaneidade dos meios de comunicação não apenas decompõem ordens sociais. Ao contrário das expectativas negativas, tais processos ensejam também a criação de identidades locais e de relações comunitárias de pequena e microescala vicinais.

Tal ponto leva à descrição inicial do livro acerca da cidade como espaço caótico de relações impessoais e anônimas, seguida da adaptação e da aclimatação do personagem Ricardo à sua rua, ao seu bairro e ao próprio Recife como um todo. O desenraizamento é uma experiência transitória por que passam os migrantes, conforme pontuado por teóricos mencionados na primeira seção deste artigo, embora ela não seja um estado imutável. O relativo caos urbano pode inscrever, a seu modo, relações provincianas e identidades regionais não dissolvidas pelos meios de comunicação de massa e pela multidão. 


\section{SOBRE OS AUTORES}

BERNARDO BUARQUE DE HOLLANDA é professor adjunto e pesquisador do Centro de Pesquisa e Documentação em História Contemporânea do Brasil da Fundação Getúlio Vargas (CPDOC/FGV). Bolsista de produtividade em pesquisa do CNPq.

E-mail: bernardo.hollanda@fgv.br https://orcid.org/oooo-oooI-778I-4684

REGIANE MATOS é doutoranda no Programa de PósGraduação em História, Política e Bens Culturais do CPDOC/FGV. Bolsista de doutorado da Capes.

E-mail: regianematos89@gmail.com

https://orcid.org/oooo-oooI-5732-4637

\section{REFERÊNCIAS}

ANDRADE, Carlos Drummond de. A rosa do povo. São Paulo: Companhia das Letras, 2012.

AZEVEDO, André Nunes de. A grande reforma urbana do Rio de Janeiro: Pereira Passos, Rodrigues Alves e as ideias de civilização e progresso. Rio de Janeiro: Ed. PUC-Rio, 2016.

BHABHA, Homi K. O local da cultura. Belo Horizonte: Humanitas, I998.

BERMAN, Marshall. Tudo que é sólido desmancha no ar: a aventura da modernidade. São Paulo: Companhia das Letras, 2007.

BOSI, Alfredo. História concisa da literatura brasileira. São Paulo: Cultrix, I975.

BRESCIANI, Maria Stella M. Londres e Paris no século XIX: o espetáculo da pobreza. São Paulo: Brasiliense, I982. CANDIDO, Antonio. O discurso e a cidade. São Paulo: Duas Cidades, I993.

;CASTELLO, José Aderaldo (Org.). Presença da literatura brasileira: modernismo - história e antologia. Rio de Janeiro: Bertrand Brasil, I997.

CARVALHO, José Murilo de. Os bestializados: o Rio de Janeiro e a república que não foi. São Paulo: Companhia das Letras, I987.

CHAGURI, Mariana. O romancista e o engenho: José Lins do Rego e o regionalismo nordestino nos anos I920 e I930. São Paulo: Hucitec, 2009.

COUTINHO, Eduardo F. A relação arte/realidade em Fogo morto. In: COUTINHO, Eduardo F; CASTRO, Ângela Bezerra de (Org.). José Lins do Rego - fortuna crítica. Rio de Janeiro: Editora Civilização Brasileira, I99I.

ELIAS, Norbert. Sobre o tempo. Rio de Janeiro: Zahar, I998.

FEATHERSTONE, Michael. Localismo, globalismo e identidade cultural. Sociedade e Estado, Brasília, v. II, n. I, I996, p. 9-42.

FREYRE, Gilberto. Sobrados e mucambos. São Paulo: Global, 2004.

GOMES, Renato Cordeiro. A cidade, a literatura e os estudos culturais: do tema ao problema. Ipotesi Revista de Estudos Literários, Juiz de Fora, v. 3, n. 2, jul.-dez. I999, p. I9-30. 
LIPOVETSKY, Gilles; SERROY, Jean. A cultura-mundo: resposta a uma sociedade desorientada. São Paulo: Companhia das Letras, $20 I I$.

LEÃO, Emmanuel Carneiro. O terceiro mundo. In: . Aprendendo a pensar. V. 2. Petrópolis: Vozes, I99I.

MELO, Virginius de Gama e. Estudos críticos. João Pessoa: Editora Universitária/UFPB, I980. . O romance político do Recife. In: COUTINHO, Eduardo; CASTRO, Ângela Bezerra e (Org.). José Lins do Rego: coleção fortuna crítica. Rio de Janeiro: Civilização Brasileira, I99I.

PROENÇA, Manuel Cavalcanti. O negro tinha caráter como o diabo!. In: REGO, José Lins do. O moleque Ricardo. Rio de Janeiro: Editora José Olympio, 20Ir.

RAMINELLI, Ronald. História urbana. In: CARDOSO, Ciro Flamarion; VAINFAS, Ronaldo (Org.). Domínios da história: ensaios de teoria e método. Rio de Janeiro: Elsevier, I997, p. I85-202.

REGO, José Lins do. O moleque Ricardo. Rio de Janeiro: José Olympio, I96I. . O moleque Ricardo. Rio de Janeiro: José Olympio, I984. O moleque Ricardo. 28. ed. Rio de Janeiro: José Olympio, 20II.

SARLO, Beatriz. Modernidade periférica: Buenos Aires, I920-I930. São Paulo: Cosac Naify, 2010.

SCHORSKE, Carl Emil. Pensando com a história: indagações na passagem para o modernismo. São Paulo: Companhia das Letras, 2000.

SODRÉ, Nelson Werneck. O pós-modernismo: José Lins do Rego e Graciliano Ramos. Rio de Janeiro: Fundação Biblioteca Nacional - Coordenadoria de Editoração, 20I4.

WILLIAMS, Raymond. O campo e a cidade na história e na literatura. São Paulo: Companhia das Letras, I989. 